\title{
Development of a non-radioactive molecular hybridization probe for detecting Strawberry mottle virus in strawberry
}

\author{
Asinari, F.; E.E. Cafrune, F.A. Guzmán, L.R. Conci and V.C. Conci
}

\begin{abstract}
SUMMARY
The vegetative propagation of strawberries favors transmission of systemic pathogens, such as viruses, which are one of the main yield-limiting factors for this crop. More than 20 viruses have been described as infecting this species; one of the most frequent is the Strawberry mottle virus (SMoV), which is responsible for significant economic losses. SMoV is usually detected by reverse transcription polymerase chain reaction (RT-PCR), given that serum is not available for serological tests. In this study, a non-radioactive molecular probe was developed for SMoV detection. The cDNA was synthesized by RT-PCR using specific primers designed from the 3'UTR region of the viral genome. The cloned cDNA segment was labeled and used as a probe. Six RNA extraction protocols were evaluated, and the modified cetyltrimethylammonium bromide (CTAB) method showed the highest sensitivity level. Leaves at different phenological stages and petioles were evaluated; the highest reaction was observed in old leaves and in petioles.
\end{abstract}

Key words: Fragaria $x$ ananassa, molecular techniques, screening viruses, virus diagnosis.

Asinari, F.; E.E. Cafrune, F.A. Guzmán, L.R. Conci y V.C. Conci, 2016. Desarrollo de una sonda de hibridación molecular no radioactiva para la detección de Strawberry mottle virus en frutilla. Agriscientia 33 (1): $39-45$

\section{RESUMEN}

La propagación vegetativa del cultivo de frutilla favorece la transmisión de patógenos sistémicos, como es el caso de los virus, que constituyen uno de los principales factores limitantes. Se han descripto más de 20 virus que infectan esta especie; el Strawberry mottle virus (SMoV) es uno de los más frecuentes y responsable de importantes pérdidas económicas. Debido a la falta de antisuero disponible comercialmente para un diagnóstico serológico, el SMoV es detectado fundamentalmente mediante reacción en cadena de la polimerasa con transcripción reversa (RT-PCR). En este estudio se desarrolló una sonda de hibridación molecular no radioactiva para su detección. Se 
sintetizó cDNA con cebadores específicos diseñados a partir de la región 3' no codificante del genoma viral. El cDNA obtenido fue clonado, marcado y utilizado como sonda. Se evaluaron seis protocolos de extracción de ARN viral a partir de plantas infectadas, de los cuales el método de bromuro de cetiltrimetilamonio modificado (CTAB) fue el más eficiente. Se evaluaron hojas de diferentes estados fenológicos y pecíolos, y fueron las hojas viejas y los pecíolos los que mostraron mayor reacción.

Palabras clave: Fragaria x ananassa, técnicas moleculares, muestreo de virus, diagnóstico de virus.

F. Asinari, E.E. Cafrune, F.A. Guzmán, L.R. Conci: Instituto de Patología Vegetal (IPAVE). Instituto Nacional de Tecnología Agropecuaria (INTA), Camino 60 Cuadras Km 5 1/2, Córdoba, (X5020lCA). V.C. Conci: IPAVE - INTA, y Consejo Nacional de Investigaciones Científicas y Técnicas (CONICET), Córdoba, Argentina. Correspondence to: conci.vilma@inta.gob.ar

\section{INTRODUCTION}

Viruses are one of the major limiting factors in strawberry (Fragaria $x$ ananassa Duch.) production, given the vegetative propagation of this specie (Martin \& Tzanetakis, 2006; Bhagwat et al., 2016). Four aphid-transmitted viruses have been detected in strawberry crops in Argentina: Strawberry mild yellow edge virus (SMYEV), Strawberry mottle virus (SMoV), Strawberry crinkle virus (SCV), and Strawberry polerovirus 1 in simple and multiple infections (Nome \& Yossen, 1980; Conci et al., 2009; Perotto et al., 2014; Luciani et al., 2016). The aphid-transmitted viruses are considered of utmost economic importance in almost all strawberry production areas around the world (Converse, 1987; Martin \& Spiegel, 1998a).

The SMoV species is not assigned to a genus and it belongs to the order Picornavirales in the family Secoviridae (King et al., 2012). The virus genome consists of two RNA1 and RNA2, which are 7036 and 5619 nucleotides long respectively, excluding the 3 ' poly (A) tail. The polyprotein of RNA1 encodes a putative protease cofactor (Pro-C), a helicase (HEL), a viral genome-linked protein (VPg), a protease (Pro) and an RNA-dependent RNA polymerase (RdRp). The polyprotein of RNA2 encodes the movement protein (MP) and the coat protein (CP) (large and small) (Thompson et al., 2002).

The SMoV is transmitted by aphids (Chaetosiphon sp. and Aphis gossypii) in a semi-persistent manner and not by direct contact between hosts or seeds. When SMoV is associated with other strawberry viruses, it is responsible for severe symptoms including dwarfism, crinkle, xanthosis, yellows, mottle, distortion or severe stunting (Converse, 1987; Martin \& Spiegel, 1998b; Luciani et al., 2016). In single infections, the virus is asymptomatic in all commercial strawberry cultivars, but severe virus strains may reduce plant vigor and yield (Converse, 1987; Martin \& Tzanetakis, 2006).

In Argentina, the increasing quality requirements for exports have called for the implementation of good agricultural practices to comply with sanitary certification before exporting. Considering that commercial antiserum is unavailable for serological testing of SMoV, the virus is usually detected by reverse transcription polymerase chain reaction (RT$\mathrm{PCR}$ ). Even though this technique is highly sensitive and specific, it turns out to be impractical because of the effort involved in making a large number of simultaneous analyses, and also because PCR testing is rather costly. Analyzing many samples at the same time is possible through serological techniques such as the enzyme-linked immunosorbent assay (ELISA); it has been shown, however, that they are not as sensitive as molecular testing (Stevens et al., 1997; Sanchez-Navarro et al., 1998; Moury et al., 2000; Lunello et al., 2005). Molecular hybridization probes are an interesting alternative for this purpose. They can test a large number of 
samples simultaneously and they are also more advantageous than serological techniques because they can detect low concentrations of pathogens (Galipienso et al., 2004; Meng et al., 2007; Aparicio et al., 2009). The aim of this work was to develop a molecular hybridization probe to detect SMoV in strawberry plants.

\section{MATERIALS AND METHODS}

\section{Plant material}

Strawberry plants cv. Camino Real showing typical symptoms of the disease such as dwarfing, stunting, mottle and leaf deformation were evaluated by RT-PCR using the SMoV specific designed primers. Two genomic RNA sequences from SMoV, published in GenBank with accession numbers AJ311875 (RNA1) and AJ311876 (RNA2), were used to design specific primers that amplify a 511 bp fragment in the 3' NCR of the SMoV genome (Table 1). The RT-PCR was performed using Access RT-PCR System ${ }^{\circledR}$ Kit (Promega, USA), following the manufacturer's instructions. Thermocycling conditions were: 35 cycles of $30 \mathrm{~s}$ at $94^{\circ} \mathrm{C}, 45 \mathrm{~s}$ at $60^{\circ} \mathrm{C}$ and 1 min at $68^{\circ} \mathrm{C}$, followed by a final extension of $7 \mathrm{~min}$ at $68^{\circ} \mathrm{C}$. The PCR products were separated by electrophoresis in $2 \%$ agarose gels and visualized under UV light after staining with ethidium bromide. Positive SMoV plants were used to evaluate the molecular probe developed in this study. Fragaria virginiana UC-12 (indicator plant) grown in a greenhouse under controlled conditions was used as negative control for virus infection (healthy control). Allium cepa L. (onion) infected with Onion yellow dwarf virus severe (OYDV-Se) was also used as negative control (heterologous control) (Celli et al., 2013).

\section{Development of cDNA detection probe}

The 511 bp amplified genomic fragment was purified with the Wizard SV gel and PCR Clean Up system ${ }^{\circledast}$ Kit (Promega, USA) from the gel and cloned in PGEM ${ }^{\circledR}-$ T Easy Vector Kit (Promega, USA) according to the manufacturer's standard instructions, and DH5a competent Escherichia coli were transformed following Sambrook et al. (1989). The DNA from the obtained clones was purified with the Plasmid Purification Qiagen kit and sequenced by the capillary electrophoresis Sanger method with a Big Dye Terminator v3.1 (Applied Biosystems) modified protocol (Unidad de Genómica, Instituto de Biotecnología, INTA). The recombinant plasmid was linearized with the Sacl restriction enzyme (New England Biolabs, USA) and labeled with dig11-dUTP by random priming using hexanucleotides and Klenow enzyme, following the manufacturer's instructions of the DIG DNA labeling and detection KIT (Roche). To evaluate the labeling efficiency and establish the concentration to be used serial dilutions from 1:10 to $1: 100,000$ were made from DIGlabeled control DNA (kit positive control, $5 \mathrm{ng} / \mu \mathrm{l}$ ), unlabeled control DNA (kit negative control) and the obtained probe (SMoV probe). One microliter of each dilution was spotted onto a nylon membrane (Amersham) and then air-dried and UV-irradiated for $3 \mathrm{~min}$; the dot-blot hybridization was performed following the manufacturer's instructions. SMoV probe concentration was estimated by comparing color intensities with the standard labeled DNA (kit positive control).

\section{Sample processing}

SMoV-infected strawberry leaves were used to select the most appropriate procedure for the molecular hybridization technique. Six different protocols were tested using protocol 1, total RNA plant extraction with RNeasy Plant Mini Kit (Qiagen); protocol 2, total RNA plant extraction with TRIzol ${ }^{\circledR}$ reagent (Invitrogen), following the manufacturer's instructions; protocol 3, total nucleic acid extraction using the modified cetyltrimethylammonium bromide (CTAB) method (Chang et al., 2007); protocol 4 , homogenized strawberry plant in extraction buffer $\left[1.3 \mathrm{~g} \mathrm{Na}_{2} \mathrm{SO}_{3} ; 20 \mathrm{~g}\right.$ PVP; $2 \mathrm{~g}$ powdered egg (chicken) albumin; $20 \mathrm{~g}$ Tween-20, in $1000 \mathrm{ml}$ of $1 \mathrm{x}$. phosphate buffered saline Tween-20 (PBST) buffer $\left(8.0 \mathrm{~g} \mathrm{NaCl} ; 1.15 \mathrm{~g} \mathrm{Na}_{2} \mathrm{HPO}_{4} ; 0.2 \mathrm{~g} \mathrm{KH}_{2} \mathrm{PO}_{4}\right.$; $0.2 \mathrm{~g} \mathrm{KCl} ; 0.5 \mathrm{~g}$ Tween-20, in $1000 \mathrm{ml}$ of distilled

Table 1. Specific primers used for detecting SMoV

\begin{tabular}{lcc}
\hline Primer & Primer sequence & Binding site of database reference \\
\hline \multirow{2}{*}{ SoFw } & 5'AGCCCAAAGAGGCTGGTGGTGTAT-3' & $6377-6400$ RNA1 \\
& & $4960-4983$ RNA2 \\
SoRv & 5'-TCAGAGCGGCCTCCAGAATTTTATTG-3' & $6861-6886$ RNA1 \\
& & 5444-5381 RNA2 \\
\hline
\end{tabular}

* The designer primers amplify a fragment of 511 bp in RNA1 and RNA2 of SMoV 
water)] with the addition of $2 \%$ Polyvinyl-polipyrrolidone (PVPP); protocol 5, homogenized strawberry plant in extraction buffer (Kaden-Kreuziger et al., 1995) with the addition of $2 \%$ PVPP and followed by the CTAB extraction method (Chang et al., 2007), starting from $200 \mu$ l of these homogenates; protocol 6, total RNA plant extraction using CTAB and $\mathrm{LiCl}$ (Zhang et al., 2013).

\section{Detection of SMoV in strawberry plants by dot- blot hybridization}

Total nucleic acid extractions using protocol 3 kept at $-80{ }^{\circ} \mathrm{C}$ were used as samples. The tests were performed with plant tissues (leaf and petiole) at different phenological stages (young, mature and old leaves) from three strawberry plants previously identified as infected with SMoV. The RT-PCR products with specific primers that amplified 511 bp of the SMoV genome were denatured at 70 and $100{ }^{\circ} \mathrm{C}$ and used as positive controls spotted in different dilutions $(1: 1,373.5 \mathrm{ng} / \mathrm{\mu l})$ onto the nylon membrane. Total nucleic acid extractions (protocol 3) from the onion plant infected with OYDV-Se was used as negative control (heterologous control). The purified recombinant plasmid DNA was used as positive reaction control.

The strawberry and onion samples were denatured for $3 \mathrm{~min}$ at $100{ }^{\circ} \mathrm{C}$ and transferred on ice for $3 \mathrm{~min}$. One $\mu \mathrm{l}$ of each sample and control were spotted onto nylon membranes. The membranes were UV-irradiated for 3 min and prehybridized at $65^{\circ} \mathrm{C}$ for 90 min in hybridization solution (5 X SSC $\mathrm{pH} 7$; $1 \%$ blocking solution; $0.1 \% \mathrm{~N}$-Lauroylsarcosine; $0.02 \%$ sodium dodecyl sulfate-SDS); then, $2 \mathrm{ng} / \mathrm{ml}$ of denaturized SMoV-probe was added and hybridized overnight at $65^{\circ} \mathrm{C}$, according to the manufacturer's instructions Dig DNA Labeling and Detection Kit (ROCHE). After hybridization, the membranes were washed twice in $2 \times \mathrm{SSC} \mathrm{pH} 7$ and $0.1 \%(\mathrm{wt} / \mathrm{vol})$ SDS for $5 \mathrm{~min}$ at room temperature (low stringency conditions) and twice in $0.5 \mathrm{X}$ SSC $\mathrm{pH} 7$ and $0.1 \%$ (wt/vol) SDS for $15 \mathrm{~min}$ at $65^{\circ} \mathrm{C}$ (high stringency conditions). They were incubated for $30 \mathrm{~min}$ in a blocking solution (2\% blocking reagent in maleate buffer $\mathrm{pH} 7.5$ [100 mM maleate acid; $15 \mathrm{mM}$ sodium chloride]) and the hybridization was detected with 1:5,000 anti-DIG antisera Alkaline phosphatase conjugate and incubated at room temperature for $30 \mathrm{~min}$, and washed twice for 15 min with maleate buffer $\mathrm{pH}$ 7.5. All the described procedures were performed with continuous shaking. The membranes were equilibrated in detection buffer pH 9.5 (100 mM Tris- $\mathrm{HCl}$ pH 9.5, 100 mM sodium chloride, $50 \mathrm{mM}$ magnesium chloride) for
$3 \mathrm{~min}$. The reaction was developed using nitroblue tetrazolium salt (NBT) and 5-Bromo-4-chloro-3-indolyl phosphate, toluidinium salt (BCIP) solution in detection buffer pH 9.5.

\section{RESULTS}

\section{RT-PCR amplification of SMoV}

The designed primers (SoFw/SoRv) allowed amplification of the expected viral genomic fragment (511 bp) using RT-PCR of strawberry plants cv. Camino Real with viral infection symptoms. No positive reactions were observed in healthy plants.

\section{DIG probe labeling efficiency}

According to the spot intensity comparison between the positive kit control and the SMoV probe, the concentration of the labeled probe was estimated at $0.5 \mathrm{ng} / \mathrm{\mu l}$ and the reaction was observed up to the $1: 1,000$ dilution (0.5 pg/ $\mathrm{\mu l}$ ) (Figure 1).

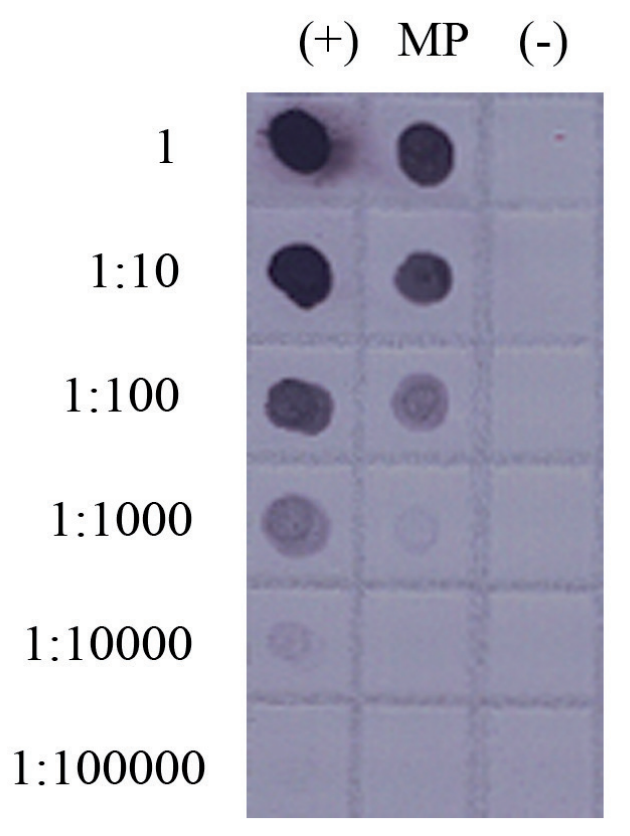

Figure 1. SMoV DIG probe labeling efficiency. Lane (+) DIGlabeled control DNA (positive control of the kit) 1 is $5 \mathrm{ng} / \mu \mathrm{l}$. Lane (MP) SMoV probe. 1 is $~ 500 \mathrm{pg} / \mu \mathrm{l}$. Lane (-) Unlabeled control DNA (negative control of the kit).

\section{Sample processing}

The modified CTAB protocol number 3 provided the best reaction intensity of the tested samples in the molecular hybridization assay. The spot inten- 
sity in the pure sample of the infected plant extraction indicated that it was able to detect $\sim 2 \mathrm{ng} / \mu \mathrm{l}$ (Figure 2, protocol 3) of viral RNA, considering it was more intense than that of the 1:1,000 dilution in the positive control (Figure 2, P2 lane). A weak spot was observed in the next 1:10 sample dilution, corresponding to $\sim 0.2 \mathrm{ng} / \mathrm{\mu l}$ compared to the control sample concentration. The RNeasy Plant Mini Kit (Qiagen) protocol (Figure 2, protocol 1) reacted only in the pure sample being estimated at $\sim 0.2$ $\mathrm{ng} / \mathrm{\mu l}$ compared with the control. Protocol 5 showed very weak reactions only in the 1:10 dilution, estimated at $\sim 0.1 \mathrm{ng} / \mathrm{\mu l}$ (Figure 2, protocol 5).

The most intense reaction for the positive controls (RT-PCR products and homologous plasmid) was observed in the material denatured at $100^{\circ} \mathrm{C}$. This control allowed detection up to $\sim 373 \mathrm{pg} / \mu \mathrm{l}$ of DNA (Figure 2, P2 lane). The negative control did not show hybridization signals (Figure 2, He lane).

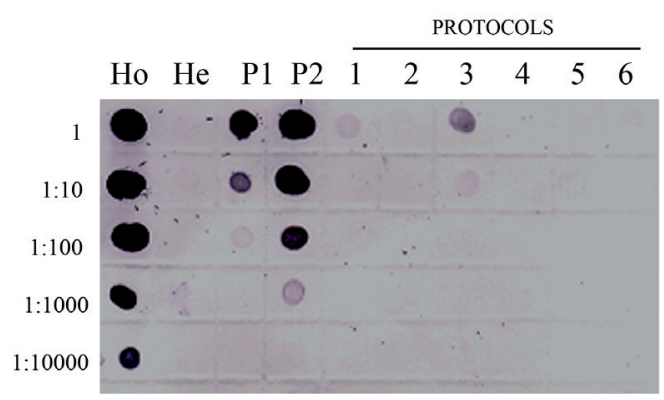

Figure 2. Comparison of different RNA extraction protocols for SMoV detection using dot-blot hybridization. Lane Ho: homologous plasmid DNA (positive reaction control, purified plasmid DNA, 1 is 906.5ng/ $\mathrm{\mu l}$ ). Lane He: heterologous DNA (negative control, onion plant DNA, 1 is $203.4 \mathrm{ng} / \mathrm{\mu l}$ ). Lane P1: RT-PCR product, amplified with specific primers, denatured at $70{ }^{\circ} \mathrm{C}$ (positive control, 1 is $373.5 \mathrm{ng} / \mathrm{\mu l}$ ). Lane P2: RT-PCR product, amplified with specific primers, denatured at $100{ }^{\circ} \mathrm{C}$ (positive control, 1 is $373.5 \mathrm{ng} / \mu \mathrm{l}$ ). Protocols 1 to 6 used to select the most appropriate procedure for nucleic acid extraction.

\section{Detection of SMoV in strawberry plants}

The SMoV probe reacted appropriately with positive control, purified plasmid DNA and the RTPCR product up to the 1:10,000 dilution ( $37 \mathrm{pg} /$ ul) (Figure $3 \mathrm{~A}$ ). The SMoV was detected in naturally infected strawberry plants using this molecular probe. Old leaves and petioles showed a slightly more marked reaction than young and mature leaves (Figure $3 \mathrm{~B}$ ). The negative control (heterologous DNA) and the healthy control (healthy plant) did not show hybridization signals (Figure $3 \mathrm{~A}, \mathrm{C}$ ).
A

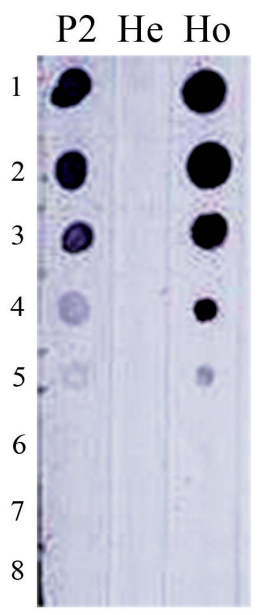

B

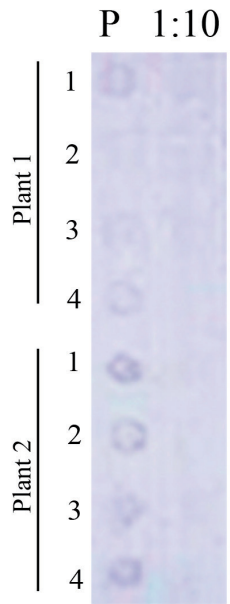

C

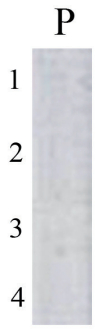

Figure 3. Evaluation of infected plant tissues at different phenological stages by dot-blot hybridization. A) Positive and negative controls for the molecular hybridization probe, in serial dilutions. 1: undiluted; 2: 1:10; 3: 1:100; 4: 1:1,000; 5: 1:10,000; 6: 1:100,000; 7: 1:1,000,000 and 8: 1:10,000,000. Ho: purified plasmid DNA (positive control). He: onion plant DNA (negative control, heterologous). P2: RT-PCR product, amplified with specific primers, denatured at $100{ }^{\circ} \mathrm{C}$ for 3 min ( 1 is $373.5 \mathrm{ng} /$ $\mu \mathrm{ll})$. B) Leaves and petiole tissues of $2 \mathrm{SMoV}$-infected plants. P. undiluted sample. 1:10 diluted sample. 1) old leaves; 2) mature leaves; 3) young leaves; 4) petioles. C) Healthy plant. P. undiluted sample. 1) old leaf; 2) mature leaf; 3) young leaf; 4) petiole.

\section{DISCUSSION}

In this work we developed a molecular digoxigenin-labeled DNA probe able to detect SMoV in naturally infected strawberry plants using a $511 \mathrm{bp}$ specific fragment from the 3' UTR region of SMoV as a probe. Molecular hybridization probes have been developed to detect many plant pathogens because they are highly sensitive and easy to use (Galipienso et al., 2004; Liu et al., 2007; Aparicio et al., 2009). This detection system was found to be low cost and it did not require highly specialized equipment.

Quality requirements for exporting strawberry plants include health certification. The best alternative for massive detection would be using a serological test, such as ELISA, but a specific SMoV antiserum is not available. To date, only the RT-PCR system has been used to detect SMoV because no other system was available, let alone for massive diagnoses.

The molecular probe can directly detect the virus from the infected strawberry plant tissues reli- 
ably enough to be used in routine procedures, given that it is highly sensitive and can simultaneously test a large number of samples.

The SMoV probe efficiency tests show an adequate labeling degree. The color intensity up to the $1: 1,000$ probe dilution was similar to that obtained with the 1:10,000 dilution of the positive control provided by the kit, equivalent to $0.5 \mathrm{pg} / \mathrm{\mu l}$ of labeled DNA in pure spot. The modified CTAB extraction (protocol 3) yielded the best results, followed by the RNeasy Plant Mini Kit (Qiagen), which reacted only in the pure sample. By contrast, protocol 5 showed a slight reaction in the 1:10 dilution, but it failed to show any reaction in pure solution, probably because of impurities in the undiluted sample that interfered in the hybridization reaction (Demeke \& Adams, 1992; Kreader, 1996).

The SMoV molecular probe was able to detect between 373 to $37 \mathrm{pg}$ of fully complementary DNA nucleotides when the labeling control reaction was made, and it showed a reaction of up to 1:1,000 or $1: 10,000$ dilution. The signal was significantly more intense when the RT-PCR product was denaturalized at $100^{\circ} \mathrm{C}$ than at $70^{\circ} \mathrm{C}$.

SMoV was detected in a dilution of up to 1:10, which means around $0.2 \mathrm{ng} / \mathrm{\mu l}$ of viral nucleic acid, displaying a weak reaction in infected plants. Previous studies indicated that molecular hybridization probes allow detection of low pathogen concentrations (Galipienso et al., 2004; Meng et al., 2007; Aparicio et al., 2009). In the particular case of strawberry viruses, concentration in plants is usually extremely low and detection is difficult (Li et al., 2014). However, the results obtained in this study showed that this probe could be a useful tool as a first detection-step to determine the phytosanitary condition of strawberry plants in routine diagnoses.

Galipienso et al. (2004) reported that nucleotide changes in the region where primers hybridize can alter the PCR results because primer annealing is more sensitive to nucleotide variations than hybridization with large-sized probes; for this reason, a genomic fragment of $511 \mathrm{bp}$ was used in this study. Li et al. (2014) also obtained a SMoV probe with a genomic fragment smaller than the one used in this work; however, the labeling efficiency could not be compared because they did not show it.

Identifying the best plant tissue to detect the virus is an important tool to make a reliable diagnosis for disease management programs. In this study, the pathogen was detected at all phenological stages of leaves and petioles, but the reaction was more intense in old leaves and petioles. The molecular hybridization probe developed in this work is an alternative to the RT-PCR technique for
SMoV detection. Our results support the view of Galipienso et al. (2004) in that a disadvantage of RT-PCR is the cost and time involved in each tested sample and the fact that primer annealing is more sensitive to nucleotide variations than hybridization with large-sized probes. The molecular hybridization probe is a more practical test than RT-PCR and useful for massive screening considering that SMoV serological tests are not available.

\section{ACKNOWLEDGEMENTS}

This work was supported by Instituto Nacional de Tecnología Agropecuaria (INTA) of Argentina and Agencia Nacional de Promoción Científica y Tecnológica of Argentina through a FONCyT grant. The authors wish to thank Verónica Milagros Trucco for her technical assistance, Lorena Giachero for taking photos of the membrane and Marcos Celli for supplying the nucleic acid of onion plants infected with OYDV-Se.

\section{REFERENCES}

Aparicio, F.; S. Soler, J. Aramburu, L. Galipienso, F. Nuez, V. Pallás and C. Lopez, 2009. Simultaneous detection of six RNA plant viruses affecting tomato crops using a single digoxigenin-labelled polyprobe. European Journal Plant Pathology 123:117-123.

Bhagwat, B.; V. Dickison, X. Ding, M. Walker, M. Bernardy, M. Bouthillier, A. Creelman, R. DeYoung, Y. Li, X. Nie, A. Wang and Y. Xiang, 2016. Genome sequence analysis of five Canadian isolates of strawberry mottle virus reveals extensive intra-species diversity and a longer RNA2 with increased coding capacity compared to a previously characterized European isolate. Archive of Virology DOI 10.1007/s00705-016-2799-6

Celli, M.G.; A.K. Torrico, M. Kiehr and V.C. Conci. 2013. Striking differences in the biological and molecular properties of onion and garlic isolates of Onion yellow dwarf virus. Archive of Virology 158(6):1377-1382.

Chang, L.; Z. Zhang, H. Yang, H. Li and H. Dai, 2007. Detection of strawberry RNA and DNA viruses by RTPCR using total nucleic acid as a template. Journal of Phytopathology 155:431-436.

Conci, V.C.; A.K. Torrico, E.E. Cafrune, V. Quevedo, O. Baino, J.C. Ramallo, A.M. Borquez, V.A. Mollinedo, J.J. Agüero and D.S. Kirschbaum, 2009. First report of Strawberry mild yellow edge virus in Argentina. Acta Horticulturae 842:303-306.

Converse, R.H., 1987. Virus diseases of small fruits. Ed. U.S. Dep. Agric. Agric. Handb. 631. U.S. Government printing office, Washington, DC., 277 pp. 
Demeke, T. and R.P. Adams, 1992. The effects of plant polysaccharides and buffer additives on PCR. Biotechniques 12:332-334.

Galipienso, L.; M.C. Vives, L. Navarro, P. Moreno and J. Guerri, 2004. Detection of citrus leaf blotch virus using digoxigenin-labeled cDNA probes and RT-PCR. European Journal Plant Pathology 110:175-181.

Kaden-Kreuziger, D.; S. Lamprecht, R.R. Martin and W. Jelkmann, 1995. Immunocapture polymerase chain reaction assay and elisa for the detection of Strawberry mild yellow edge associated potexvirus. Acta Horticulturae 385:33-38.

King, A.M.Q.; M.J. Adams, E.B. Carstens and E.J. Lefkowitz, 2012. Virus Taxonomy: Ninth Report of the International Committee on Taxonomy of Viruses. Academic Press, pp. 835-899.

Kreader, C. 1996. Relief of amplification inhibition in PCR with bovine serum albumin or T4 gene 32 protein. Applied and Environmental Microbiology 62:1102-1106.

Li L.; H. Yang, M. Zhao and Y. Lai, 2014. Detection of Strawberry mottle virus by molecular hybridization. Journal of Chemical and Pharmaceutical Research, 6:426-429.

Liu, Y.; B. Sun, X. Wang, C. Zheng and G. Zhou, 2007. Three digoxigenin-labeled cDNA probes for specific detection of the natural population of Barley yellow dwarf viruses in China by dot-blot hybridization. Journal of Virological Methods 145:22-29.

Luciani, C.E.; M.G. Celli, M.C. Merino; M.C. Perotto; I.E. Pozzi and V. C. Conci, 2016. First report of Strawberry polerovirus 1 in Argentina. Plant Disease100 (7):1510.

Lunello, P.; D. Ducasse and V.C. Conci, 2005. Improved PCR detection of potyviruses in Allium species. European Journal of Plant Pathology 112:371-378.

Martin, R.R. and I.E. Tzanetakis, 2006. Characterization and recent advances in detection of strawberry viruses. Plant Disease 90:384-396.

Martin, R.R. and S. Spiegel, 1998a. Aphid-Borne viruses. In Maas, J.L. (Ed.): Compedium of strawberry diseases. APS press, St. Paul, Minessota, pp. 63-674.

Martin, R.R. and S. Spiegel, 1998b. Strawberry mottle virus. In Maas, J.L. (Ed.): Compedium of strawberry diseases. APS press, St. Paul, Minessota, pp. 66-67.

Meng, J.; Q. Gu, S. Lin, B. Peng, L. Liu, Y. Tian and L. $\mathrm{Li}, 2007$. Dot-blot hybridization for detection of five cucurbit viruses by digoxigenin labelled cDNA probes. Agricultural Sciences in China 6:1450-1455.

Moury, B.; L. Cardin, J.P. Onesto, T. Candresse and A. Poupet, 2000. Enzyme-linked immunosorbent assay testing of shoots grown in vitro and the use of the immunocapture reverse transcription-polymerase chain reaction improve the detection of Prunus necrotic ring spot virus in rose. Phytopathology 90:522-528.

Nome, S.F. y V. Yossen,1980. Identificación de virus de frutilla en Argentina. I. Virus del moteado de frutilla (Strawberrymottle virus). Revista de Investigaciones Agropecuarias INTA XV:245-258.

Perotto, M.C.; C. Luciani, M.G. Celli, A.K. Torrico and V.C. Conci, 2014. First report of Strawberry crinckle virus in Argentina. New Disease Reports 30:5. http://dx. doi.or g/10.5197/j.20440588.2014.030.005

Sambrook, J.; E.F. Fritsch, T. Maniatis, 1989. Molecular cloning: a laboratory manual. 2. ed., 3. vol., Cold Spring Harbor Laboratory Press, New York.

Sanchez-Navarro, J.A.; F. Aparicio, A. Rowhani and V. Pallas, 1998. Comparative analysis of ELISA non radioactive molecular hybridization and PCR for the detection of Prunus necrotic ringspot virus in herbaceous and prunus host. Plant Pathology 47:780-786.

Stevens, M.; R. Hull and H.G. Smith, 1997. Comparison of ELISA and RT-PCR for the detection of Beet yellows closterovirus in plants and aphids. Journal of Virological Methods 68:9-16

Thompson, J.R.; G. Leone, J.L. Lindner, W. Jelkmann and C.D. Schoen, 2002. Characterization and complete nucleotide sequence of Strawberry mottle virus: a tentative member of a new family of bipartite plant picorna-like viruses. Journal of General Virology 83:229239.

Zhang, Y.J.; X.Y. Hao, Z.S. Liang, W.D. Ke and H.B. Guo, 2013. Efficient isolation of high-quality RNA from lotus Nelumbo nucifera ssp nucifera tissues. Genetics and Molecular Biology 12:223-229. 